\title{
Chapter I \\ Explanatory notes on tourism in protected areas of Croatia and Slovenia
}

\author{
Vuk Tvrtko Opačić, Miha Koderman
}

\section{Abstract}

In this chapter, IUCN categories of protected areas are defined, along with categories of protected areas in Croatia and Slovenia with emphasis on the harmonisation thereof with IUCN categories. Additionally, the intent of each individual category of protected area in Croatian and Slovenian legislation is explained, in order to assess the possibility of their tourism valorisation and make a comparison. Tourism develops and influences space in different ways throughout the world. This means that in the most visited protected areas, tourism has become one of the key factors for transformation of protected areas and their surroundings. In contrast, tourism is not strongly developed in less-popular protected areas, and their scientific, educational, and recreational functions are stronger than tourism.

Key words: categories of protected areas, IUCN, tourism, Croatia, Slovenia

\section{Introduction}

Increasing demand for tourism and recreational activities in protected areas has many positive and also negative environmental consequences. Managers of protected areas face important dilemmas when they decide 
between policies that strengthen nature conservation and consequently limit the progress of tourism related activities, and those that allow more moderate development of protected areas, thus enabling the growth of their recreational function. In the last decade, integrated management of protected areas has striven towards the implementation of the concept of sustainable tourism development. Although this concept has become widely accepted and has been successfully introduced in some protected areas, it is still often inappropriately and/or inadequately carried out in regard to its theoretical assumptions. Additionally, there is a frequent lack of concrete research aimed at identifying the spatial effects of tourism on the basis of defined and measurable indicators of the state of the environment.

The International Union for Conservation of Nature and Natural Resources (IUCN in further text) defines a protected area as 'a clearly defined geographical space, recognised, dedicated, and managed, through legal or other effective means, to achieve the long-term conservation of nature with associated ecosystem services and cultural values' (Leung et al., 2018). IUCN's definition of protected areas is partially included in both Croatian and Slovenian legislation that relates to nature protection (Berginc et al., 2006; Marković, 2015). According to Croatian Nature Protection Act (Official Gazette, 8o/13) a protected area is defined as a 'geographically clearly-defined area that is intended for nature protection and in which long-term actions for nature protection and ecosystem preservation are carried out'. In Slovenian legislation, nature protection is covered by the Nature Conservation Act (1999), the fundamental legal act that has been amended many times since its inception.

Protected areas are established in order to protect species and habitats, together with ecosystem services and natural processes (Sovinc, 2017) and can be classified into several categories concerning the level of conservation or management goals (Tab. 1).

It is important to mention that each state determines categories according to its own criteria, so the categories from different states that bear the same name might not actually be analogous in terms of level and manner of protection (Klarić and Gatti, 2006). In order to unify the criteria for declaring certain categories of protected areas on the global level, the tendency in most states is to implement the IUCN categorisation of protected areas (Dudley, 2008; Leung et al., 2018). Examples of harmonisation of categories of protected areas, as well as deviation from IUCN categorisation, are visible in some cases in Croatia and Slovenia. 
Tab. I IUCN protected area categories

\begin{tabular}{|c|c|c|}
\hline $\begin{array}{l}\text { IUCN } \\
\text { type }\end{array}$ & $\begin{array}{c}\text { Name } \\
\text { of the category }\end{array}$ & Definition \\
\hline Ia & Strict nature reserve & $\begin{array}{l}\text { Strictly protected for biodiversity and also possibly geological/ } \\
\text { geomorphological features, where human visitation, use and im- } \\
\text { pacts are controlled and limited to ensure protection of the con- } \\
\text { servation values. These areas are primary used for scientific re- } \\
\text { search and monitoring. }\end{array}$ \\
\hline $\mathrm{Ib}$ & Wilderness area & $\begin{array}{l}\text { Usually large unmodified or slightly modified areas, retaining } \\
\text { their natural character and influence, without permanent or sig- } \\
\text { nificant human habitation, protected and managed to preserve } \\
\text { their natural condition. }\end{array}$ \\
\hline II & National park & $\begin{array}{l}\text { Large natural or near-natural areas protecting large-scale eco- } \\
\text { logical processes with characteristic species and ecosystems, } \\
\text { which also have environmentally and culturally compatible } \\
\text { spiritual, scientific, educational, recreational and visitor oppor- } \\
\text { tunities. }\end{array}$ \\
\hline III & $\begin{array}{l}\text { Natural monument } \\
\text { or feature }\end{array}$ & $\begin{array}{l}\text { Areas set aside to protect a specific natural monument, which } \\
\text { can be a landform, sea mount, marine cavern, geological feature } \\
\text { such as a cave, or a living feature such as an ancient grove. This } \\
\text { category usually comprises of smaller areas with important sig- } \\
\text { nificance for visitors. }\end{array}$ \\
\hline IV & $\begin{array}{l}\text { Habitat/species man- } \\
\text { agement area }\end{array}$ & $\begin{array}{l}\text { Areas to protect particular species or habitats, where manage- } \\
\text { ment reflects this priority. Many will need regular, active inter- } \\
\text { ventions to meet the needs of particular species or habitats, but } \\
\text { this is not a requirement of the category. }\end{array}$ \\
\hline $\mathrm{V}$ & $\begin{array}{l}\text { Protected landscape } \\
\text { or seascape }\end{array}$ & $\begin{array}{l}\text { Where the interaction of people and nature over time has pro- } \\
\text { duced a distinct character with significant ecological, biological, } \\
\text { cultural and scenic value: and where safeguarding the integrity } \\
\text { of this interaction is vital to protecting and sustaining the area } \\
\text { and its associated nature conservation and other values. }\end{array}$ \\
\hline VI & $\begin{array}{l}\text { Protected areas with } \\
\text { sustainable use of } \\
\text { natural resources }\end{array}$ & $\begin{array}{l}\text { Areas which conserve ecosystems, together with associated cul- } \\
\text { tural values and traditional natural resource management sys- } \\
\text { tems. Generally large, mainly in a natural condition, with a pro- } \\
\text { portion under sustainable natural resource management and } \\
\text { where low-level non-industrial natural resource use, compatible } \\
\text { with nature conservation, is seen as one of the main aims. }\end{array}$ \\
\hline
\end{tabular}

Source: according to Leung et al., 2018, adapted by authors

\section{Categories of protected areas in Croatia and Slovenia}

According to data of the Ministry of Environment and Energy of the Republic of Croatia (2019c), protected areas encompass $8.54 \%$ of the total area of the Republic of Croatia, i.e. $12.22 \%$ of land territory and $1.94 \%$ of sea territory. Of all categories of protected areas in Croatia, the greatest amount of area is given to nature parks, ahead of significant landscapes, re- 


\section{gional, and national parks. Categories of protected areas in Croatia are di- vided by legislation according to the IUCN categorisations, as shown in Tab. 2, while their spatial distribution is shown in Fig. 1.}

Tab. 2 Types of protected areas in Croatia

\begin{tabular}{|c|c|c|c|c|c|}
\hline $\begin{array}{c}\text { Category } \\
\text { of protection }\end{array}$ & Purpose & $\begin{array}{l}\text { Manage- } \\
\text { ment level }\end{array}$ & $\begin{array}{c}\text { IUCN } \\
\text { category }\end{array}$ & $\begin{array}{l}\text { Number } \\
\text { of areas }\end{array}$ & $\begin{array}{c}\text { Surface } \\
\left(\mathrm{km}^{2}\right)\end{array}$ \\
\hline $\begin{array}{l}\text { Strict } \\
\text { reserve }\end{array}$ & $\begin{array}{l}\text { Conservation of original } \\
\text { nature, nature monitoring, } \\
\text { and education. }\end{array}$ & $\begin{array}{l}\text { National } \\
\text { and } \\
\text { regional }\end{array}$ & Ia & 2 & 24.19 \\
\hline $\begin{array}{l}\text { National } \\
\text { park }\end{array}$ & $\begin{array}{l}\text { Conservation of original natural } \\
\text { values; scientific, cultural, educa- } \\
\text { tional, tourism, and recreation- } \\
\text { al purpose. }\end{array}$ & National & II & 8 & 979.63 \\
\hline $\begin{array}{l}\text { Special } \\
\text { reserve }\end{array}$ & $\begin{array}{l}\text { Conservation of natural phe- } \\
\text { nomena due to uniqueness, rar- } \\
\text { ity, representativeness, and/or } \\
\text { particular scientific significance. }\end{array}$ & $\begin{array}{l}\text { National, } \\
\text { regional, } \\
\text { local }\end{array}$ & IV & 77 & 400.11 \\
\hline Nature park & $\begin{array}{l}\text { Protection of biological and } \\
\text { landscape diversity; educational, } \\
\text { cultural, historical, tourism, and } \\
\text { recreational purpose. }\end{array}$ & National & $\mathrm{V}$ & 11 & 4320.48 \\
\hline Regional park & $\begin{array}{l}\text { Landscape diversity protection, } \\
\text { sustainable development, and } \\
\text { tourism. }\end{array}$ & Regional & $\mathrm{V}$ & 2 & 1025.56 \\
\hline $\begin{array}{l}\text { Natural } \\
\text { monument }\end{array}$ & $\begin{array}{l}\text { Environmental protection; sci- } \\
\text { entific, aesthetic, or education- } \\
\text { al purpose. }\end{array}$ & $\begin{array}{l}\text { Regional } \\
\text { and local }\end{array}$ & III & 80 & 2.27 \\
\hline $\begin{array}{l}\text { Significant } \\
\text { landscape }\end{array}$ & $\begin{array}{l}\text { Protection of landscape val- } \\
\text { ue and biodiversity; protection } \\
\text { of cultural and historical value; } \\
\text { protection of landscape with pre- } \\
\text { served unique features; rest and } \\
\text { recreation. }\end{array}$ & $\begin{array}{l}\text { Regional } \\
\text { and local }\end{array}$ & $\mathrm{V}$ & 82 & 1331.28 \\
\hline Park forest & $\begin{array}{l}\text { Conservation of natural or plant- } \\
\text { ed forests of great landscape val- } \\
\text { ue; rest and recreation. }\end{array}$ & $\begin{array}{l}\text { Regional, } \\
\text { local }\end{array}$ & - & 27 & 29.54 \\
\hline $\begin{array}{l}\text { Horticultural } \\
\text { monument }\end{array}$ & $\begin{array}{l}\text { Preservation of a horticultural- } \\
\text { ly shaped space or plant(s) with } \\
\text { aesthetic, stylistic, artistic, cul- } \\
\text { tural, historical, ecological, or } \\
\text { scientific value. }\end{array}$ & Regional & - & 119 & 8.36 \\
\hline \multicolumn{5}{|c|}{ Area of protected areas within other protected areas } & 593.39 \\
\hline TOTAL & & & & 408 & 7528.03 \\
\hline
\end{tabular}

Sources: Marković, 2015, according to Zupan, 2012; Ministry of Environment and Energy of the Republic of Croatia, 2orga 


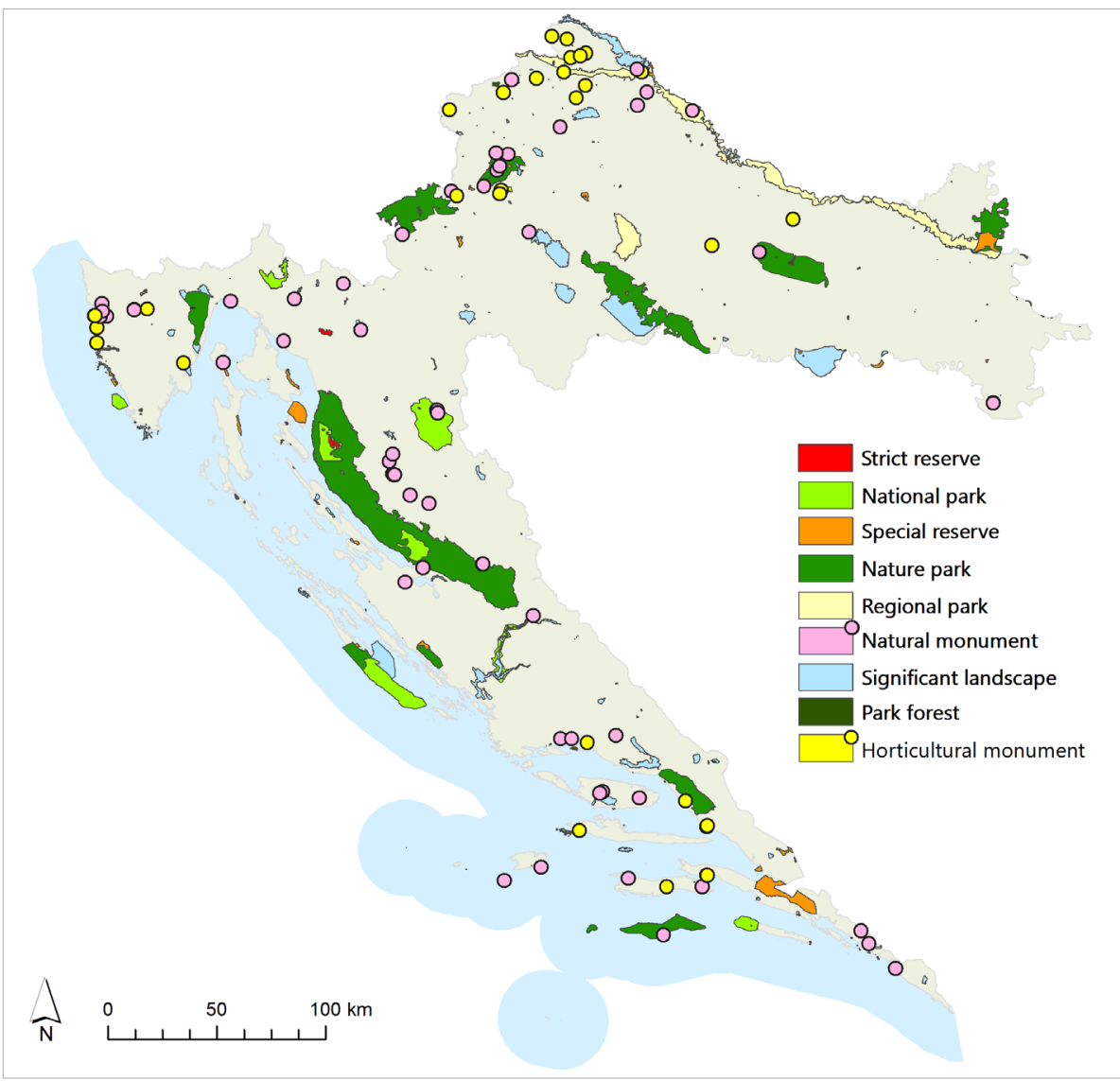

Fig. I Spatial distribution of protected areas in Croatia

Source: Ministry of Environment and Energy of the Republic of Croatia, 2019c

In regard to the level of management, the highest level (state) is characteristic for national parks, nature parks, strict reserves, and special reserves. As far as the level of protection goes, strict reserves are the most protected and are not meant for mass, organised tourist visits. This means that such areas are essentially irrelevant in terms of tourism valorisation. It can be said that national parks (Bralić, 200o) and nature parks-with regard to their size and intended use-are by far the most important and most-visited type of protected area in Croatia (See: Chapter 2). Namely, each national park and nature park is managed by the state via a competent public institution that is charged with nature protection and development of other economic activities like tourism, recreation, education, and promotion (Opačić et al., 2005). 
This serves to strengthen the institutional and financial sustainability of the national system of protected areas in Croatia, and also facilitates the cooperative marketing presentation of all Croatian national and nature parks included in the project "Parks of Croatia" (Ministry of Environment and Energy of the Republic of Croatia, 2017) (See: Chapter 11). This cooperative presentation and promotion on the tourism market has resulted in significant growth in the number of visitors to the parks in question over the last few years (See: Chapter 2).

It is worth mentioning that protected areas are declared in order to protect nature, and not to strengthen tourism and/or recreation. Sustainable tourism in most protected areas, however, is a welcome activity, as shown in Tab. 2. Thereby, with regard to leisure activities, it is worth differentiating the role of national parks, which attract both foreign and domestic tourists (Vidaković, 2003), from nature parks-some of which are more oriented toward tourism, while others are oriented toward recreation on the part of the local population (Opačić et al. 2014). National parks distinguish themselves in terms of attractiveness and number of visitors, like other protected areas that have been recognised by UNESCO as exceptionally valuable and given the status of World Heritage Site (e.g. Plitvice Lakes National Park in Croatia and Škocjan Caves Regional Park in Slovenia) (Holden, 2013).

The majority of remaining categories of protected areas in Croatia are not included in the tourism and/or recreation supply to the same degree, rather they have a conservational and educational role that stem from their value as part of Croatia's natural heritage. Such areas are managed by public institutions that have been founded in each of Croatia's 21 counties (regional-level management), and in some cases by cities, towns, municipalities, and special public institutions.

According to the Nature Conservation Act (1999), protected areas of nature in Slovenia are, on a basic level, divided into larger (national park, regional park, landscape park) and smaller areas (strict natural reserve, nature reserve, natural monument). The categories of all protected areas, their purpose and compliance with the IUCN categorisation are shown in Tab. 3, while their spatial distribution in Slovenia is shown in Fig. 2. 
Tab. 3 Types of protected areas in Slovenia

\begin{tabular}{|c|c|c|c|c|}
\hline $\begin{array}{c}\text { Category } \\
\text { of protection }\end{array}$ & Purpose & $\begin{array}{c}\text { IUCN } \\
\text { category }\end{array}$ & $\begin{array}{c}\text { Number } \\
\text { of areas }\end{array}$ & $\begin{array}{c}\text { Surface } \\
\left(\mathrm{km}^{2}\right)\end{array}$ \\
\hline National park & $\begin{array}{l}\text { A large area with many natural values } \\
\text { and with a high level of biodiversity cov- } \\
\text { ering the majority of the national park; } \\
\text { the original nature with preserved eco- } \\
\text { systems and natural processes is present; } \\
\text { there may also be areas in a smaller por- } \\
\text { tion of the national park of greater hu- } \\
\text { man influence, which is in harmony with } \\
\text { nature. }\end{array}$ & $\begin{array}{l}\text { II (at least } \\
75 \%) \text { and } \\
\text { V (a max- } \\
\text { imum of } \\
25 \%)\end{array}$ & 1 & 839.82 \\
\hline Regional park & $\begin{array}{l}\text { An extensive area of regionally impor- } \\
\text { tant ecosystems and landscapes with } \\
\text { larger parts of the original nature and ar- } \\
\text { eas of natural values, which are inter- } \\
\text { twined with areas of nature where hu- } \\
\text { man influence is greater. }\end{array}$ & $\begin{array}{l}\text { V (at least } \\
75 \%) \text {, and } \\
\text { II (a max- } \\
\text { imum of } \\
25 \%)\end{array}$ & 3 & 429.91 \\
\hline Landscape park & $\begin{array}{l}\text { An area with emphasised qualitative and } \\
\text { long-term interaction between man and } \\
\text { nature, which has many ecological and } \\
\text { landscape values, and/or a high level of } \\
\text { biodiversity. }\end{array}$ & $\mathrm{V}$ & 46 & 1299.71 \\
\hline Strict natural reserve & $\begin{array}{l}\text { An area of naturally conserved geotopes, } \\
\text { habitats of endangered, rare or charac- } \\
\text { teristic plant or animal species, or an } \\
\text { area importance for the conservation of } \\
\text { biodiversity, where natural processes oc- } \\
\text { cur without human impact. }\end{array}$ & I & 1 & 0.02 \\
\hline Nature reserve & $\begin{array}{l}\text { An area of geotopes, habitats of endan- } \\
\text { gered, rare, or typical plant or animal } \\
\text { species, or an important area for the con- } \\
\text { servation of biodiversity, which is also } \\
\text { maintained through balanced human ac- } \\
\text { tivity in nature. }\end{array}$ & IV & 56 & 54.96 \\
\hline Natural monument & $\begin{array}{l}\text { An area containing one or more natural } \\
\text { values that have exceptional shape, size, } \\
\text { content, or position, or are a rare exam- } \\
\text { ple natural values. }\end{array}$ & III & 1164 & 192.69 \\
\hline TOTAL & & & 1271 & 2817.11 \\
\hline
\end{tabular}

Sources: Berginc et al., 2006; Sovinc et al., 2011; Slovenian Environment Agency, 2019

Protected areas in Slovenia amount to $2,817.11 \mathrm{~km}^{2}$ (in 2019), thus covering $\mathbf{1 3 . 9 \%}$ of Slovenia's surface area (Slovenian Environment Agency, 2019). Considering the relationship between protection and development, protected areas in Slovenia can be classified into 4 groups (Lampič et al., 2011, 6o-61): 1) protected areas in which protection excludes development (strict 


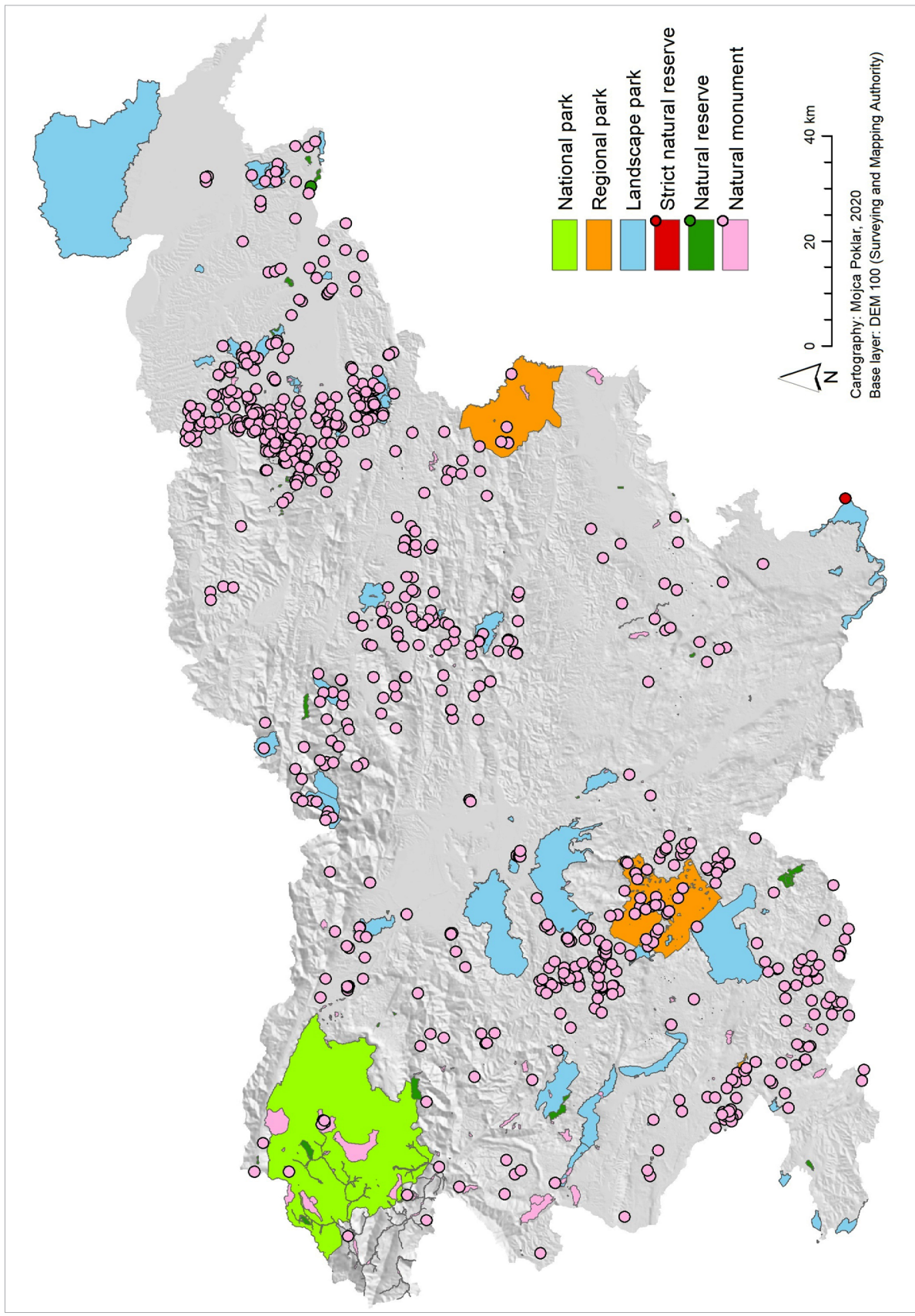

Fig. 2 Spatial distribution of protected areas in Slovenia Source: Slovenian Environment Agency, 2019 
nature reserves, IUCN type Ia and Ib); 2) category "equilibrium", where protection and development are equally important (regional and landscape parks, IUCN type V);3) conservation-oriented protected areas in which protection has priority over development (national parks, IUCN type II; natural monuments; IUCN type III); and 4) development-oriented protected areas, where development has priority, while respecting protection regimes, biodiversity, and important habitats (areas in Natura 2000 and ecologically significant areas).

Although the main role of protected areas can be attributed to the protection and conservation of nature (protection, maintenance, and restoration of habitats, as well as regular and continuous monitoring of the state of the park and its impact area), one cannot overlook their educational and research value, as well as their contribution to the development of the wider areas around them and human activities - aimed at greater socio-economic well-being in general (Hribar et al., 2011). As an example, tourist and recreational activities in protected areas can also be pointed out. In Slovenia, Triglav National Park plays a dominant role among protected areas, as it covers over 4 percent of the country's territory. Its leading role is also reflected in the category of nature protection (it is the only national park in Slovenia) and in tourist and recreational visits (Groznik Zeiler, 2011), as it is visited by over 2 million visitors annually (Triglav National Park, 2016). Other categories of protected areas register a significantly lower number of visitors; they are mostly visited by domestic visitors and tourists who usually visit a broad tourism area.

It should be mentioned that Slovenia has no regional administrative level of political governance, which is why only national and local levels of governance exist (although the plans for a regional administrative level of political governance were introduced in 2007). Despite this fact, there are three regional parks in Slovenia, which by definition represent large areas of regionally characteristic ecosystems and landscapes. They are managed by the municipalities (LAU 2) in which the protected areas are located, or by public institutions. Such level of protected area management can represent a problem in terms of financing, management, and organisation of work.

In both countries, a significant part of territory is also included in the Natura 2000 network, which is undoubtedly positive in terms of nature protection. The share of protected areas in Slovenia is $32.4 \%$ (Natura 2000, 2019) and in Croatia 29.3\% (Ministry of Environment and Energy of the Republic of Croatia, 2019b). In terms of tourism development, the areas of 
the Natura 2000 network that are also already protected under other categories of nature protection are very important. In the described context, such smaller protected areas (including those in Natura 2000 network) are usually declared to be of "local" importance and are therefore the concern of local communities-mainly municipalities. In such cases, the budget for protected areas is limited and protected areas are sometimes regarded as development restrictions by the local population (Mrak, 2008).

A comparison of the structure of protected areas in Croatia and Slovenia according to category shows quite a few differences between the two states. This is somewhat surprising because these are small, neighbouring states which share nearly identical natural regions (Pannonian lowlands, Dinarides, Adriatic coast). Apart from this, the most important part of the development of protected areas in both states actually took place when they were both part of the same state: the Socialist Federal Republic of Yugoslavia.

The category of nature park, which accounts for the largest portion of the total area of territory with protected status in Croatia, does not exist in Slovenia. The category that is most similar to the Croatian nature park category in Slovenia is either regional or landscape park, but there are major differences in the manner of management. The only category of protected area that, by definition and significance for ecology and tourism among protected areas, is essentially the same in both states is national park. It is interesting that this category also best corresponds to the IUCN definition, which confirms the key significance of national parks among protected areas on the global level. Furthermore, the major aforementioned differences, connected to levels of management of protected areas, stem from the lack of regional-level governance in Slovenia.

\section{Context and structure of the book}

At first glance, nature protection and tourism or recreation are incompatible activities. An increase in the number of visitors to a given protected area can have various negative impacts, like water, air, soil, and noise pollution, and reductions in the number and diversity of plant and animal species. This negatively influences biodiversity, and visually degrades the area (e.g. traffic and other tourism/hospitality infrastructure) (Mihalič, 2006; Cigale, 2009; Marković Vukadin, 2017).

Conversely, a protected area should be understood as a site of valuable natural heritage, and one of the most important functions of natu- 
ral (or cultural) heritage is to educate visitors. Protected areas are popularised by their inclusion in the tourism supply, thus becoming important goals for tourism and recreational mobilities. Under conditions of globalisation and the everyday stress of living in cities, the contemporary tourist is increasingly interested in learning about the values of local nature areas (Newsome et al., 2013) - especially protected areas. As a consequence of the aforementioned trend, there has been recognised growth in the significance of nature-based tourism (Coghlan and Buckley, 2013), ecotourism (Fennell, 2013), and tourism in protected areas specifically. 'Equally the term ecotourism should be understood as promotion of non-mass travel in naturally sensitive, protected areas where the visitor would raise public awareness towards preserving the natural environment and therewith, with its activities support the local community (Gosar, 2017, 3-4)'.

The aforementioned forms of tourism show numerous advantages, as they take place within paradigms of sustainable development, for both protected areas and the wider area, i.e. community or state. Namely, increased income (from tickets, souvenirs, guided tours, etc.) for protected areas ensures additional resources that, along with investment in nature protection, increase the value of the area in the long term (Bushell and McCool, 2007), and also influence increasing ecological awareness of visitors and the local population. From the aspect of tourism, the most attractive protected areas (e.g. Plitvice Lakes National Park or Triglav National Park) can become generators of tourism development and the entire economy of the wider area in which they are found, because their tourism branding also promotes the entire region and even the state itself. Thereby, a key precondition is that tourism capacity and the majority of its associated infrastructure should not be within the protected area.

It should be mentioned that the influence of such national parks on the wider area is not always positive. Regarding the example of the village Saborsko on the border of Plitvice Lakes National Park, Kušen and Klarić (2000) emphasised that the foundation of a national park can disrupt traditional rural systems, i.e. the daily lives of the local population. In this context, national parks can be seen as 'a foreign body in a previously unnoticed rural area' (Kušen and Klarić, 2000, 440)".

The main theme of this collection of research is comparative analysis of spatial development of tourism in protected areas in Croatia and Slovenia from a geographical perspective, in order to identify similarities and differences. Apart from confirmation of the spatial implications of tourism in 
protected areas in both states, another goal was to compare the development of tourism and its spatial influence and impacts in selected case studies. Guided by this objective, relevant experts on the topic of tourism in protected areas from both countries were invited to highlight the presented topic via their work on representative case studies.

Transport and transport infrastructure are an unavoidable precondition and development factor for tourism in all types of tourism areas, including protected areas. Therefore, the second chapter is dedicated to the topic of transport accessibility in Croatian national parks and nature parks. The authors examine its connection to tourist flow through analysis of five indicators, including public transport connectivity, public transport frequency, road transport connectivity, and temporal distance from urban areas and larger tourist centres.

Some national parks that are visited by a large number of tourists can be recognised as bearers of tourism, encompassing the wider area around the protected area itself. Examples of such national parks are Krka and Mljet national parks in Croatia. The research regarding Krka National Park presented in the third chapter, focuses on the development of rural tourism in its surrounding area, which has been characterised by intense development of rural tourism in recent years. The fourth chapter deals with the influence of tourism on the demographic development of the island Mljet in southern Dalmatia, which has become a popular tourism destination since its northwestern part was declared a national park in 1960. The research focuses on the socio-economic transformation and social pressure of tourism on a small local community.

Although the transformative role of tourism in lesser-known protected areas (most often those of a lower level of protection) is significantly weaker, wider knowledge of their conservational and educational role within the framework of nature-based tourism is very valuable and aids in guiding future development and management of protected areas. Additionally, it is also important to research the geographical aspects of recreational activities in protected areas, such as various forms of active recreation (mountaineering, fishing, birdwatching), as well as secondary housing. Protected areas on the Slovenian coast and in the Dinaric karst region are good examples for this.

The fifth chapter of this book discusses the influence of climate change on protected areas along the Slovenian coast. The Sečovlje Saltpans, Strunjan, and Debeli Rtič landscape parks and Škocjanski zatok Nature Reserve represent "islands of nature" in the mostly urbanised coastal zone 
of Slovenia, which is why they became important primarily as leisure areas and secondarily as tourism areas. With the goal of confirming possibilities for the development of nature-based tourism in rural areas of Kraški Rob, the sixth chapter of this book contains a scored assessment of the attractiveness of natural attractions and their tourism accessibility.

The seventh chapter of the book deals with second homes, as a form of recreation and potentially also of tourism in protected areas (Natura 2000). The described phenomenon is presented using the example of the village Sviščaki in forested area around Snežnik Mountain — the highest mountain in Slovenia that is outside of the Alps. Regarding the example of Škocjanski zatok Nature Reserve, the eighth chapter of the book shows the transformation of a once-degraded area in the vicinity of the port city Koper, which has become a protected marsh area with educational and tourism/recreational functions, due to the process of renaturalisation.

The last three chapters are dedicated to the planning of tourism and management in protected areas from the aspect of tourism in both states. The ninth chapter tackles spatial planning in tourism in protected areas in Slovenia, and primarily gives an overview of planning on different levels (national to local), before examining them using the examples of Škocjanski zatok Nature Reserve, Lipica (Natura 200o), and Škocjan Caves Regional Park. The tenth chapter discusses the interrelation between development, management, and management issues in Plitvice Lakes National Park - the most visited protected area in Croatia. In this chapter, phases of tourism development according to Butler's model (TALC) and the related management phases and approaches are presented.

The last chapter synthesises the main findings of the research presented in the previous chapters and integrates these findings into recommendations for future management of protected areas, in keeping with the concept of sustainable tourism.

\section{Conclusion}

It can be concluded that protected areas differ in intended purpose, in relation to both IUCN categorisation and categorisation in Croatia and Slovenia. One of the main differences between the Croatian and Slovenian systems of protected areas is that there are more types of protected areas in Croatia (9 in total) than in Slovenia (6 in total). In Croatia, there is a higher number of "large" protected areas (national parks, nature parks), while 
in Slovenia the number of small scale protected areas is higher $(1,164$ nature monuments).

There are also large differences in the scope and characteristics of tourism in individual categories of protected areas. Some of them (e.g. national parks) can satisfy a wide spectrum of tourism motivations with what they offer and, therefore, attract numerous tourists of general motivation, while other categories (e.g. natural monuments) generally only attract specific groups of visitors. In contrast, some protected areas with stricter protection regimes (e.g. strict natural reserves) essentially do not participate in the organised tourism supply, regardless of their inherent attractiveness and natural beauty. Finally, some protected areas (especially those in the vicinity of cities, e.g. nature parks or park forests) are ideal for recreation on the part of the local population and, in these areas, leisure/recreational activities are much more developed than tourism.

In the most-visited national parks tourism (often mass tourism-especially during the summer tourism season) has become the main factor of transformation of both protected areas and the areas surrounding them. Namely, the surrounding area brings both positive and negative changes, occasionally threatening nature protection imperatives, i.e. the fundamental function of all protected areas. In contrast, in lesser-known protected areas, i.e. those with a lower level of protection, tourism is the initial phases or not present, so their scientific, educational, and recreational functions are more strongly emphasised than tourism (commercial). As a specific dominant form of tourism in such areas, nature-based tourism stands out. The spatial reflection of such tourism is gentler and also has the effect of spreading ecological awareness and educating visitors.

\section{References}

Berginc, M., Kremesec Jevšenak, J., Vidic, J., 2006: Sistem varstva narave $v$ Sloveniji, Ministrstvo za okolje in prostor, Ljubljana.

Bralić, I., 200o: Turizam i nacionalni parkovi u Hrvatskoj, Turizam 48 (4), 373-378.

Bushell, R., McCool, S. F., 2007: Tourism as a tool for conservation and support of protected areas: setting the agenda, in: Tourism and protected areas: benefits beyond boundaries (eds. Bushell, R., Eagles, P.), CAB International, Oxfordshire - Cambridge, 12-26. 
Cigale, D., 2009: Turizem in rekreacija kot dejavnika okoljskih obremenitev, in: Okoljski učinki prometa in turizma v Sloveniji (eds. Špes, M., Ogrin, D.), Univerza v Ljubljani, Filozofska fakulteta, Ljubljana, 86-105.

Coghlan, A., Buckley, R., 2013: Nature-based tourism, in: The Routledge handbook of tourism and the environment (eds. Holden, A., Fennell, D.), Routledge, London - New York, 334-344.

Dudley, N. (ed.), 2008: Guidelines for applying protected area management categories, IUCN, Gland.

Fennell, D., 2013: Ecotourism, in: The Routledge handbook of tourism and the environment (eds. Holden, A., Fennell, D.), Routledge, London - New York, 323-333.

Gosar, A., 2017: Managing sustainable tourism in protected areas, in: Tourism in protected areas of nature in Serbia and Slovenia (eds. Filipović, D. et al.), University of Belgrade, Faculty of Geography, Belgrade, 3-11.

Groznik Zeiler, K., 2011: Razvojna vloga zavarovanih območij v Sloveniji, in: Razvoj zavarovanih območij v Sloveniji (eds. Nared, J. et al.), Geografski inštitut Antona Melika ZRC SAZU, Ljubljana, 23-32.

Holden, A., 2013: Protected areas and tourism, in: The Routledge handbook of tourism and the environment (eds. Holden, A., Fennell, D.), Routledge, London - New York, 276-284.

Hribar, M., Šmid Hribar, M., Erhartič, B., 2011: Premislek o razvoju in zavarovanih območjih, in: Razvoj zavarovanih območij v Sloveniji (eds. Nared, J. et al.), Geografski inštitut Antona Melika ZRC SAZU, Ljubljana, 11-21.

Klarić, Z., Gatti, P., 2006: Ekoturizam, in: Hrvatski turizam: plavo, bijelo, zeleno (eds. Čorak, S., Mikačić, V.), Institut za turizam, Zagreb, 149-165.

Kušen, E., Klarić, Z., 200o: Razvoj turizma u rubnim područjima nacionalnih parkova: primjer Saborsko, Turizam 48 (4), 439-446.

Lampič, B., Mrak, I., Plut, D., 2011: Geographical identification of development potential for the sustainable development of protected areas in Slovenia, Hrvatski geografski glasnik 73 (2), 49-65, DOI: 10.21861/hgg.2011.73.02.04.

Leung, Y. F., Spenceley, A., Hvenegaard, G., Buckley, R. (eds.), 2018: Tourism and visitor management in protected areas: guidelines for sustainability, Best Practice Protected Area Guidelines Series No. 27, IUCN, Gland.

Marković, I., 2015: Problemi i mogućnosti održivoga upravljanja zaštićenim prirodnim područjima: primjer Nacionalnoga parka Plitvička jezera, 
Doctoral Thesis, University of Zagreb, Faculty of Science, Department of Geography, Zagreb.

Marković Vukadin, I., 2017: Sustainability issues in management of tourism in protected areas: case study of Plitvice Lakes National Park, in: Evolution of destination planning and strategy: the rise of tourism in Croatia (eds. Dwyer, L. et al.), Palgrave Macmillan, Cham, 201-219, DOI: 10.1007/978-3-319-42246-6_10.

Mihalič, T., 2006: Trajnostni turizem, Ekonomska fakulteta, Ljubljana.

Ministry of Environment and Energy of the Republic of Croatia, 2017: Projekt PARCS - pregled rezultata, Zagreb.

Mrak, I., 2008: Small size protected areas - development potentials of Slovenia, Hrvatski geografski glasnik 70 (1), 5-23, DOI: 10.21861/hgg.2008.70.01.01.

Newsome, D., Moore, S. A., Dowling, R. K., 2013: Natural area tourism: ecology, impacts and management, Channel View Publications, Bristol - Buffalo - Toronto.

Opačić, V. T., Curić, D., Jandras, M., Kutle, K., Marijan, N., Mirt, I., Perković, D., Vodanović, I., 2014: Zaštićena područja kao rekreacijske zone grada primjer Parka prirode Medvednica, Hrvatski geografski glasnik 76 (1), 6187, DOI: 10.21861/HGG.2014.76.01.04.

Opačić, V. T., Lukić, A., Fuerst-Bjeliš, B., 2005: Sustainable development of recreation and tourism in the protected areas of Croatia: issues and indicators, Problemi na geografijata 3-4, 209-223.

Sovinc, A., 2017: Explanatory notes on international standards for planning tourism and use of natural resources in some categories of protected areas, in: Tourism in protected areas of nature in Serbia and Slovenia (eds. Filipović, D. et al.), University of Belgrade, Faculty of Geography, Belgrade, 13-26.

Sovinc, A., Fišer, Pečnikar, Ž., Gosar, A., 2011: Govorimo isti jezik? Primerjava mednarodnih in slovenskih meril kategorizacije zavarovanih območij, in: Razvoj zavarovanih območij v Sloveniji (eds. Nared, J. et al.), Geografski inštitut Antona Melika ZRC SAZU, Ljubljana, 33-40.

Vidaković, P., 2003: Nacionalni parkovi i zaštićena područja u Hrvatskoj, Fond za stipendiranje mladih za zaštitu prirode i turizam Zagreb - 1990, Zagreb.

\section{Sources}

Ministry of Environment and Energy of the Republic of Croatia, 2019a: Croatian Agency for the Environment and Nature, Zagreb, http://www. 
haop.hr/hr/tematska-podrucja/zasticena-podrucja/zasticena-podrucja/ zasticena-podrucja-u-rh (28. 11. 2019)

Ministry of Environment and Energy of the Republic of Croatia, 2019b: Natura 2000 Network Database, Croatian Agency for the Environment and Nature, Zagreb.

Ministry of Environment and Energy of the Republic of Croatia, 2019c: Nature Protection Database, Croatian Agency for the Environment and Nature, Zagreb.

Natura 2000, 2019: Natura 2000 v Sloveniji, http://www.natura2ooo.si/index. php?id $=45$ (29. 11. 2019)

Nature Conservation Act, 1999: Uradni list RS 56/99.

Republic of Croatia, 2013: Nature Protection Act, Official Gazette 80/2013.

Slovenian Environment Agency, 2019: http://kazalci.arso.gov.si/sl/content/zavarovana-obmocja- 4 ?tid $=40$ (o9. 12. 2019)

Triglav National Park, 2016: Management Plan for the Triglav National Park 2016-2025, https://www.tnp.si/assets/Javni-zavod/Nacrt-upravljanja/JZTNP-Nacrt-upravljanja-TNP-2016-2025.pdf (22. 11. 2019) 